\title{
O DIREITO À ALIMENTAÇÃO NA PANDEMIA: O PRINCÍPIO JURÍDICO DA FRATERNIDADE COMO GARANTIA DE SAÚDE E DESENVOLVIMENTO.
}

\author{
Francisco Gerlandio Gomes dos Santos ${ }^{1}$ \\ Carlos Augusto Alcântara Machado
}

\section{RESUMO}

A pandemia de COVID-19 já levou à morte mais de cem mil brasileiros. A doença impõe um debate sobre o papel do Estado na segurança alimentar e na agricultura sustentável, que foram diretamente atingidas pelo isolamento social. $\mathrm{O}$ presente artigo, fruto a pesquisa exploratória doutrinária, objetiva fundamentar atuação do Poder Público durante a pandemia, pelo Princípio da Fraternidade, para a realização do Objetivo de Desenvolvimento Sustentável 02 da Organização das Nações Unidas, que prevê metas para erradicação da fome, melhoria da segurança alimentar, da nutrição e da agricultura sustentável.

PALAVRAS-CHAVE: Pandemia. Alimentação. Agricultura. Desenvolvimento Sustentável. Fraternidade.

\section{THE RIGHT TO FOOD IN PANDEMIA: THE FRATERNITY'S LEGAL PRINCIPLE AS A GUARANTEE OF HEALTH AND DEVELOPMENT.}

\begin{abstract}
The COVID-19 pandemic has already killed more than one hundred thousand Brazilians. The disease imposes a debate on the role of the State in food security and sustainable agriculture, which were directly affected by social isolation. This article, as result of exploratory doctrinal research, aims to support the performance of the Public Power during the pandemic, by the Principle of Fraternity, for the achievement of Sustainable Development Objective 02 of the United Nations, which sets goals for the eradication of hunger, improvement of food security, nutrition and sustainable agriculture.
\end{abstract}

KEYWORDS: Pandemic. Food. Agriculture. Sustainable development. Fraternity.

\section{INTRODUÇÃO}

Diante da Pandemia de COVID 19, verificou-se no Brasil um desconcerto entre políticas públicas nas esferas federal, estadual e municipal. No entanto, houve prevalência das orientações da Organização Mundial de Saúde acerca do distanciamento social e do recolhimento domiciliar, repercutindo diretamente na produção e consumo de alimentos.

\footnotetext{
1. Mestrando em Direito pela UFS. Especialista em Gestão Estratégica de Segurança Pública, pelo ISEIB Delegado de Polícia Civil do Estado de Sergipe. Endereço postal: Rua Dulce Diniz, 1050, ap. 1203/P, Luzia, Aracaju/SE, CEP 49048-430. Endereço eletrônico: fgerlandiogsantos@gmail.com.

${ }^{2}$ Doutor pela PUC-SP(2014). Mestre pela UFC (1999). Professor de Direito Constitucional da UFS e da UNIT/SE. Procurador de Justiça do Ministério Público do Estado de Sergipe. Endereço postal: Av. Barão de Maruim, 277, ap. 502, Aracaju/SE, CEP 49015-040. Endereço eletrônico: cmachado@infonet.com.br.
}

Revista Brasileira de Filosofia do Direito | e-ISSN: 2526-012X | Encontro Virtual | v. 6 | n. 2 | p. $01-21$ | Jul/Dez. 2020. 
Esse cenário traz à tona uma grave questão: como persistir na busca pelo atingimento do Objetivo de Desenvolvimento Sustentável 02 - ODS 02 - fixado na Agenda 2030 da Organização das Nações Unidas, que consiste em acabar com a fome, alcançar a segurança alimentar e melhoria da nutrição, além de promover a agricultura sustentável.

O presente artigo busca demonstrar que a aplicação do Princípio da Fraternidade às ações estatais - políticas públicas e institutos normativos - redunda em melhoria da Saúde Pública e, consequentemente, do Desenvolvimento Sustentável, imprescindível ao atingimento do ODS 02.

Valendo-se de metodologia e pesquisa exploratória, com método dedutivo, por meio de técnicas de pesquisa bibliográfica e legislativa sobre o tema, o estudo em questão traz inicialmente um breve histórico da Fraternidade, sua secularização e posterior configuração jurídica, especificando o respectivo fundamento constitucional e dimensões.

Após, analisar-se-á, abstratamente, o fundamento constitucional dos atos normativos que impuseram distanciamento social e recolhimento domiciliar, verificando se atenderam ao Princípio da Fraternidade, considerando o meio de transmissão da doença viral e a percepção contemporânea dos riscos sociais.

Em seguida, será evidenciado que os brasileiros, mesmo limitados a ficar em casa, não adotaram hábitos alimentares saudáveis; ao contrário, empreenderam maior consumo de alimentos industrializados. Nesse ponto, será analisado se o Estado brasileiro se norteou pelo princípio em foco.

Expõe-se, num último momento, que, embora o país desfrute de excelentes condições naturais para o implemento da agropecuária sustentável, a atividade não tem trazido benefícios ao meio ambiente. A insegurança alimentar no campo persiste e os alimentos não chegam à mesa livres de produtos nocivos à saúde pública. Discute-se, então, se a Fraternidade Jurídica pode nortear ações estatais visando à reorganização desse cenário, de forma a torná-lo fértil ao Desenvolvimento Sustentável.

\section{DO PRINCÍPIO DA FRATERNIDADE: BREVE HISTÓRICO, FUNDAMENTOS E DIMENSÕES}

A Fraternidade já era objeto da atenção de Aristóteles, ao tratar da amizade em Ética a Nicômaco (2003, p. 173-175): 


\begin{abstract}
Aqueles que fundamentam sua amizade no interesse, amam-se por causa da sua utilidade, por casa de algum bem que recebem um do outro, mas não amam um ao outro por si mesmos. O mesmo se pode dizer a respeito dos que se amam por causa do prazer; não é por causa do caráter que os homens amam as pessoas espirituosas, mas porque as consideram agradáveis. Desse modo, os que amam as outras por interesse, amam pelo que é bom para eles mesmos, e os que amam em razão do prazer, amam em virtude do que é agravável a eles, e não porque o outro é a pessoa amada, mas porque ela é útil ou agradável.
\end{abstract}

A primeira significação filosófica de Fraternidade é de cunho individualista, ou seja, procura justificar a relação de uma pessoa com outra, sem uma perspectiva coletiva, podendose concluir que o engatinhar da Fraternidade já é inter-relacional, mas ainda não no sentido de uma relação individuo $\mathrm{x}$ sociedade.

Já na perspectiva religiosa (cristã), a Fraternidade transcende ao coletivo, porém, inicialmente para reforçar o modelo social tribal, portanto, sectário. Somente no Novo Testamento, é que se percebe uma noção cosmopolita da Fraternidade:

Mas há, ainda, outras passagens bíblicas, também inseridas no Novo Testamento, que caracterizam o universalismo da Fraternidade cristã: 'não haverá mais grego nem judeu, nem bárbaro nem cita, nem escravo nem livre, mas somente Cristo, que será tudo em todos' (Carta de São Paulo aos Colossenses - Cap. 3, versículo 11). De igual forma, na Carta de São Paulo aos Gálatas (Gl 3, 28): “Já não há judeu nem grego, nem escravo nem livre, nem homem nem mulher, pois todos vós sóis um em Cristo Jesus(MACHADO, 2017, p. 47).

O choque cultural do Iluminismo, buscando uma integral ruptura com a Religião, não abandonou a ideia de Fraternidade, mas a secularizou, dando-lhe uma dimensão política. Nesse sentido, os discursos de Robespierre ${ }^{3}$ e Girardin ${ }^{4}$ (MACHADO, 2017, p. 26-31) são tidos como seminais dessa politização da Fraternidade.

Robespierre discursou perante a Assembleia Nacional Francesa. Defendeu que os Guardas Municipais utilizassem um emblema no uniforme com a inscrição "o Povo francês" e "Liberdade, Igualdade e Fraternidade". Girardin defendeu a "Fraternidade universal" no Clube dos Cordeliers, que já aceitava cidadãos passivos, ou seja, aqueles que não tinham direito a voto censitário, além das mulheres.

Maximilien François Mari Isidore de Robespierre, Advogado e Político (1758-1794)

René Louis de Girardin (1735-1808), o Marquês de Girardin, ou Marquês de Vauvray.

Revista Brasileira de Filosofia do Direito | e-ISSN: 2526-012X | Encontro Virtual | v. 6 | n. 2 |

p. $01-21$ | Jul/Dez. 2020. 
No entanto, após secularizada, a Fraternidade não teve a mesma concreção dos demais princípios da tríade francesa - a Liberdade e a Igualdade, que levou Antonio Maria Baggio a chamá-lo de Princípio Esquecido5 ${ }^{5}$ O resgate contemporâneo da Fraternidade, enquanto princípio político, conduz a uma questão de ordem interna, que é saber se ela tem espaço na Constituição do Brasil.

É preciso pontuar, de fato, que a Constituição Federal de 1988 só registrou expressamente a Fraternidade no seu Preâmbulo - "sociedade fraterna". Tendo em vista que a expressão "sob a proteção de Deus", também constante do Preâmbulo, foi considerada pela doutrina e jurisprudência dominantes como desprovida de carga jurídica, justificando a existência do Estado laico, não se desconsidera a possibilidade de que "sociedade fraterna", ali expressa, também seja acusada da mesma míngua normativa.

Contudo, são situações distintas. MACHADO (2017, p. 144) esclarece que, entre os objetivos fundamentais da República Federativa do Brasil, a busca pela erradicação da pobreza e da marginalização; a redução de desigualdades sociais e regionais e a promoção do bem de todos, sem preconceitos de origem, raça, sexo, cor, idade e quaisquer outras formas de discriminação (art. $3^{\circ}$, II a IV, CF) ${ }^{6}$ são determinantes para a materialização de uma sociedade fraterna. Mas não só!

O Constituinte, ao garantir o direito de propriedade (art. $5^{\circ}, \mathrm{XXII}-\mathrm{CF}$ ), relativizou seu aspecto de direito individual, passando a exigir que a propriedade atenda a sua função social (art. $5^{\circ}$, XXIII - CF). E, nos termos do art. 170/CF ${ }^{7}$, assinalou a concepção de um "Estado não intervencionista, aparentemente liberal, ou neo liberal" (MACHADO, 2017, p.

\footnotetext{
${ }^{5}$ Sob organização do autor, O Princípio Esquecido reúne artigos científicos que apontam a natureza de princípio político da Fraternidade, e indicam sua aplicação nas relações internacionais.

6 "Art. $3^{\circ}$ Constituem objetivos fundamentais da República Federativa do Brasil: I - [...]; II - garantir o desenvolvimento nacional; III - erradicar a pobreza e a marginalização e reduzir as desigualdades sociais e regionais; IV - promover o bem de todos, sem preconceitos de origem, raça, sexo, cor, idade e quaisquer outras formas de discriminação." Disponível em: http://www.planalto.gov.br/ccivil_03/constituicao/constituicao.htm. Acesso em 27 set. 2020.

${ }^{7}$ Art. 170. A ordem econômica, fundada na valorização do trabalho humano e na livre iniciativa, tem por fim assegurar a todos existência digna, conforme os ditames da justiça social, observados os seguintes princípios: I soberania nacional; II - propriedade privada; III - função social da propriedade; IV - livre concorrência; V defesa do consumidor; VI - defesa do meio ambiente, inclusive mediante tratamento diferenciado conforme o impacto ambiental dos produtos e serviços e de seus processos de elaboração e prestação; VII - redução das desigualdades regionais e sociais; VIII - busca do pleno emprego; IX - tratamento favorecido para as empresas de pequeno porte constituídas sob as leis brasileiras e que tenham sua sede e administração no País. Parágrafo único. É assegurado a todos o livre exercício de qualquer atividade econômica, independentemente de autorização de órgãos públicos, salvo nos casos previstos em lei. Disponível em http://www.planalto.gov.br/ccivil_03/constituicao/constituicao.htm. Acesso em: 27 set. 2020.
} 
144), que garante a defesa do consumidor e do meio ambiente, além de buscar a redução das desigualdades sociais e regionais e o pleno emprego.

Ademais, por imposição constitucional foi imposto à coletividade o dever de defender e preservar o meio ambiente (art. 225/CF); bem como se exige da família e da sociedade o dever de assegurar prioridade absoluta aos direitos da criança e do adolescente (art. 227, CF), além de proteger os idosos (art. 230, CF).

Como se percebe, não faltam no texto constitucional normas que se pautam pelo Princípio da Fraternidade, enquanto norteador de uma sociedade desenvolvida, ou seja, capaz de ressignificar a Igualdade (fortalecendo a Democracia) e a Liberdade (efetivando condições reais de escolhas individuais).

Acrescente-se que o Supremo Tribunal Federal, no julgamento da ADI 2649-6/DF, sob a relatoria da Ministra Carmen Lúcia, superou o entendimento anterior do STF quanto à natureza normativa do preâmbulo (ADI 2076/AC), reconhecendo valores constantes do preâmbulo, em forma de princípio, que se projetam no articulado normativo, como por exemplo no art. $3^{\circ}$, já citado nesse estudo. Nessa linha de compreensão, destaca-se, como explicitado no acórdão citado, o princípio jurídico da solidariedade; neste artigo, identificado como fraternidade.

É exatamente nesse sentido que já se concluiu doutrinariamente: a Fraternidade é o equilíbrio $^{8}$ (MACHADO, 2017, p. 162) da Liberdade e da Igualdade. Arremata o autor: "A Fraternidade é uma categoria jurídica e está amparada no texto constitucional vigente. E como categoria jurídica, se constitui no elemento indispensável para advento do constitucionalismo fraternal” (MACHADO, 2017, p. 219). Mas, afinal, qual o conteúdo da Fraternidade jurídica? Barzotto $^{9}$ (2018, p.85 e 86), amparado em Paul Ricoeur, responde a esta questão a partir de uma ideia de Reconhecimento:

Se o 'ver' pode ser ligado à ideia de conhecer - 'vejo(conheço) que x é maior que y', o 'ver como' é expresso adequadamente com o verbo 'reconhecer'. Reconhecer o outro é 'vê-lo como' um irmão. Ver/conhecer é constatar; reconhecer/ver como é operar uma analogia, o que exige uma decisão consciente por parte de quem reconhece, ao contrário do ver/conhecer, que na maior parte das vezes, é um fenômeno espontâneo.

8 Como ensina Baggio, a Fraternidade é o princípio regulador dos outros dois (BAGGIO, 2008, p. 54). Já para Clara Cardoso Machado Jaborandy, em sua tese de doutoramento - A Fraternidade no Direito Constitucional Brasileiro: um Instrumento Para Proteção de Direitos Fundamentais Transidividuais - p. 71, a Fraternidade "é vetor interpretativo na construção de significado de outros enunciados". 
Com base nas lições do autor, é possível concluir que o Reconhecimento se traduz em Solidariedade, Respeito e Reciprocidade. A primeira ressoa com mais nitidez nas relações verticais entre pessoas, entre quem precisa e quem pode ajudar, ou seja, apresenta um conteúdo mais aproximativo da caridade, do combate à miséria; o Respeito se revela com mais clareza nas relações horizontais, em que nenhum dos indivíduos esteja em situação de miséria, ou seja, os homens se veem em posição de relativa igualdade, daí porque um dá ao outro o tratamento que entende justo para si próprio; por último, a Reciprocidade impede que uma pessoa, ou um grupo delas, torne-se detentor de maiores direitos e menos deveres do que os demais, evitando o surgimento de castas de privilegiados, de maneira que, havendo alguma norma que imponha tratamento diferenciado a alguma pessoa, ou grupo, essa norma seja pautada pelas reais causas de diferenciação, e não para conferir meros privilégios injustificáveis.

No plano das relações internacionais, as Nações Unidas adotam a Fraternidade como vetor de condução social, desde a promulgação de sua Declaração Universal dos Direitos Humanos: “Art. 1'. Todos os seres humanos nascem livres e iguais em dignidade e direitos. São dotados de razão e consciência devem agir em relação uns aos autores com espírito de Fraternidade".

Marco Aquini, em obra coletiva (2008, p. 133), invocando também os artigos 28 e 29 da mesma norma, conclui que a Declaração não é mera exortação retórica do instituto, pois “a Fraternidade não se apresenta apenas como enunciação de um conceito, mas como princípio ativo, motor do comportamento da ação dos homens, com uma conotação essencialmente moral". E, assim, apresenta três aspectos (2008, p. 144-146) que vinculam Fraternidade ao Desenvolvimento Social.

Um primeiro aspecto está relacionado ao papel dos Estados na aplicação do Direito ao Desenvolvimento, adotando políticas adequadas de inserção das ONG's e empresas numa assistência econômica mundial, não limitada apenas à promoção de ações emergenciais em benefício de países não desenvolvidos; em outro aspecto, o Direito ao Desenvolvimento precisa ser um direito da pessoa e dos povos, não só dos povos, ou seja, o indivíduo passa a ser titular de relações jurídicas mais infensas a determinismos político-geográficos; já no último aspecto, o Direito ao Desenvolvimento se limita a um conteúdo meramente 
econômico, devendo ainda propiciar ao indivíduo crescimento político, cultural e social.

O Brasil, assim como qualquer Estado, precisa concretizar a Fraternidade como princípio político nas suas relações internacionais e, internamente, dar-lhe concretude de norma estruturante do próprio Estado brasileiro, vez que a Fraternidade se mostra humanistamente inclusiva (Art. $1^{\circ}$, III, CF), de modo a incrementar nos princípios da Liberdade e da Igualdade a noção de que todos são igualmente responsáveis pelo bem de todos, impedindo absurdos como a fome.

\section{DO DISTANCIAMENTO SOCIAL COMO EXPRESSÃO DA FRATERNIDADE JURÍDICA}

Ao reconhecer que "o homem é um animal metafísico", Alain Supiot (2007, p. VII) atribui à língua materna a primeira fonte de significado para o ser humano. Esse inicial referencial dogmático evidencia que já nascemos dependentes, não apenas para nosso desenvolvimento biológico, mas também para nosso desenvolvimento enquanto seres integrantes de um corpo coletivo. O homem nasce livre, mas jamais se torna integralmente independente.

Essa relação de interdependência nem sempre é ideal. Alguns homens buscam dominar os outros. Surge então a escravidão, uma monstruosa relação humana em que um ser humano subjuga outro, dominando-o, pelos mais diversos motivos, e das mais variadas formas. Nesse sentido, Laurentino Gomes afirma:

Desde tempos imemoriais até muito recentemente, portanto, a captura, a venda e o cativeiro de gente foi parte da vida de quase todos os povos e sociedades. Essa triste realidade, infelizmente, ainda persiste nos dias de hoje, sob outros disfarces. Legalmente nenhum país admite mais a escravidão, nos moldes antigos, em que seres humanos podiam ser comprados ou vendidos como mercadorias Ainda assim, muitos a permitem na prática, incluindo o Brasil, onde é recorrente o noticiário sobre pessoas submetidas a condições de trabalho análogas ao cativeiro, exploradas mediante o pagamento de salários irrisórios(ou sem isso), privadas da liberdade de ir e vir, em ambientes sórdidos ou insalubres que, muitas vezes, se assemelham aos das senzalas e dos engenhos de canade-açúcar do século XVII.(GOMES, 2019, p. 22).

Para equalizar essa interdependência e as expectativas a ela inerente, surge o Direito e em seguida, o Estado. O ente político que gerencia as liberdades humanas foi visto de várias maneiras ao longo da História. Uma visão preambular dada por Thomas Hobbes (1651) apôs no Estado o dever de proteger as pessoas, umas das outras, em troca de limitações da liberdade impostas a essas mesmas pessoas. 
Essa gerência estatal já não se restringe à locomoção. O direito de ir e vir, e de ficar, é a apenas uma dimensão da liberdade humana, sendo necessário considerar as liberdades política, educacional e econômica, que se ligam umbilicalmente ao Desenvolvimento Humano.

Explica Amartya Sem (2018, p. 6) que "o desenvolvimento consiste na eliminação de privações de liberdades que limitam as escolhas e as oportunidades das pessoas de exercer ponderadamente sua condição de agente".

O papel do Estado já não se resume a limitar a liberdade dos ofensores da ordem pública, os praticantes de crimes. O Estado passa também a assumir o dever de propiciar condições para que cada indivíduo se desenvolva enquanto componente do corpo social, permitindo-lhe condições materiais de escolha, para além da mera retórica normativa.

Essa atuação estatal não deve ser confundida com assistencialismo. Embora o programa Bolsa Família seja reconhecido pela ONU(2011) como exemplo de erradicação da pobreza, é preciso evidenciar que sua existência é exatamente a "certidão" de que o Brasil não está no mesmo patamar das nações desenvolvidas.

O Estado precisa então assegurar que oportunidades políticas, educacionais e econômicas ${ }^{10}$ estejam efetivamente ao alcance de todos, num ideal o mais próximo possível da isonomia, de forma a garantir uma ressignificação da liberdade: a opção entre a casa própria e o aluguel não pode estar entre o sonho e a realidade; a alimentação não pode estar entre o que se pode pagar e o que se precisa comer. Assim, além de limitador das liberdades, o Estado assume também o papel de fomentador delas, enquanto expressão do desenvolvimento humano.

Essa ressignificação da Liberdade tem como vetor estruturante a Fraternidade Jurídica, esclarecida por Carlos Augusto Alcântara Machado, em estudo acerca da categorização secular do instituto:

\footnotetext{
Assim, às clássicas dimensões de direitos (liberdade e igualdade) acrescentou-se uma nova e original dimensão, a fraternal. Todas - liberdade, igualdade e Fraternidade - devidamente adensadas a partir da exegese que se obtém do art. $3^{\circ}$, I, da Constituição Federal, com a identificação do primeiro objetivo jurídico do Estado brasileiro. (MACHADO, 2017, p. 219)
}

\footnotetext{
${ }^{10}$ Robério Nunes dos Anjos Filho, na obra Direito ao Desenvolvimento (2013), explica que Amartya Sen lista cinco liberdades instrumentais: a) liberdades políticas; b) facilidades econômicas; c) oportunidades sociais; d) garantias de transparência e e) segurança protetora.
} 
O cenário atual, de uma pandemia causada por um vírus sobre o qual pouco se sabe, reforça a necessidade de que a atuação estatal, para minimizar os novos obstáculos ao Desenvolvimento Sustentável, precisa estimular a Fraternidade, em equilíbrio com eventuais limitações de liberdades individuais. É como se diz: às vezes, é preciso dar um passo para atrás, para dar dois para frente.

As limitações à liberdade de locomoção e à liberdade de negociar, com a determinação de fechamento dos estabelecimentos comerciais e imposição de multas pelo descumprimento da quarentena, apresentam um componente substancialmente fraterno, qual seja o de preservar o bem-estar nacional, positivado no art. 23 da Constituição Federal.

Nesse sentido, a Portaria Interministerial de número 133, de 23 de março de 2020, uma das primeiras medidas do Governo Federal de enfrentamento à pandemia de COVID 19, determinou a restrição excepcional e temporária de entrada no Brasil de estrangeiros provenientes de determinados países, conforme recomendação da Agência Nacional de Vigilância Sanitária - Anvisa.

A medida se mostra legítima diante do alto poder de propagação do vírus SARSCOV-2, e tem esteio na nossa Carta Fundamental:

\footnotetext{
A saúde é direito de todos e dever do Estado, garantido mediante políticas sociais e econômicas que visem à redução do risco de doença e de outros agravos e ao acesso universal e igualitário às ações e serviços para sua promoção, proteção e recuperação.(Constituição Federal, Art. 196, sem negrito no original).
}

A interligação entre Economia e Saúde Pública nunca foi tão evidente, quanto nesse momento de crise pandêmica. A sociedade se viu num dilema: perder o emprego ou perder a vida.

Consideradas essenciais, algumas atividades não foram suspensas durante a pandemia, e os respectivos trabalhadores tiveram que comparecer a seus postos de trabalho, com acréscimo de dificuldades, em razão das medidas que suspenderam o transporte público em várias cidades do país.

O isolamento social, a quarentena e o lockdown, ações ${ }^{11}$ sugeridas pela Organização

\footnotetext{
${ }^{11}$ Bruno Carbinatto, na edição virtual, de 05 de maio de 2020, da Revista Superinteressante, Seção Saúde, explica que a expressão quarentena não expressa rigor técnico, vez que compreende tanto o Distanciamento Social Ampliado, que consiste no fechamento de estabelecimentos cujo funcionamento substancialmente dependente de aglomeração; quanto o Distanciamento Social Seletivo, que impõe restrições apenas à parcela da população que integra os grupos de riscos. Já o isolamento social, trata-se do trato individualizado de
} 
Mundial de Saúde como mecanismo de contenção do vírus, passaram a surgir como produto de decretos estaduais e municipais, não ocorrendo uma aplicação uniforme no país. As medidas se diferenciam em intensidade, mas são essencialmente limitações de aspectos da liberdade, que estão em harmonia com o art. 198 da Constituição Federal, ao dispor que as ações e serviços públicos de saúde integram uma rede regionalizada e hierarquizada e constituem um sistema único.

Considerando as incertezas do vírus, a postura fraternal pela qual todos se limitam para o bem de todos se revela como imprescindível, cabendo à sociedade e ao Estado adotar as ações necessárias a que esse período crítico seja transposto com o mínimo de abalo à saúde humana e à economia do País, a começar pela alimentação saudável, resultante de uma agropecuária sustentável.

\section{DO PAPEL DO ESTADO NA PRESERVAÇÃ̃ DA SAÚDE ALIMENTAR DURANTE O DISTANCIAMENTO SOCIAL: A IMPOSIÇÃO DE LIMITES COMO APLICAÇÃO DO PRINCÍPIO DA FRATERNIDADE}

Em entrevista à INFOAMAZONIA, David Quammen ${ }^{12}$ explica que a migração de doenças de animais silvestres para seres humanos está associada à degradação ambiental e a perturbações na biodiversidade causadas pelo ser humano.

Ulrich Bech (2019, p. 27/28), associando a criação de riscos diretamente ao desenvolvimento de forças produtivas, observa que "riscos da modernização são big business. Eles são as necessidades insaciáveis que os economistas sempre procuram”. E mais: os riscos socialmente reconhecidos "contêm um peculiar ingrediente político".

A pandemia deixa então uma lição de início: o ser humano precisa rever imediatamente sua alimentação, tanto porque estamos sujeitos a novas zoonoses, quanto pelo fato de que é exatamente a alimentação que nos garante um sistema imunológico eficiente.

pessoas com indicativos ou diagnóstico da doença. Por último, o lockdown se configura em maior intensidade de Distanciamento Social, e contempla o isolamento total de determinadas áreas geográficas, pela força policial, inclusive.

${ }^{12}$ Ver entrevista completa em https://infoamazonia.org/pt/2020/04/portugues-david-quammen-o-biografo-dasgrandes-epidemias/\#!/story=post-41529, acesso em 21 de junho de 2020. Vale ressaltar que o entrevistado é autor de Spillover, livro escrito há dez anos e no qual o escritor prenunciou que uma pandemia poderia resultar da migração de doenças de animais silvestres para seres humanos. 
Afora esse ensinamento, devemos observar que a crise pandêmica se mostrou palco de um debate político, em que linhas ideológicas foram radicalizadas, surgindo uma aparente dicotomia: tratar da saúde pública impõe preterimento da economia? A resposta a esta questão, evidentemente, é negativa. Se saúde pública e economia se excluíssem mutuamente, por certo, a sociedade mundial já teria chegado ao ocaso.

Ainda não há certeza científica quanto a todos os aspectos do vírus e da doença, mas autorizadas vozes, a exemplo de Luc Montagnier ${ }^{13}$, prêmio Nobel de Medicina de 2008, observam que o "comportamento viral" põe em dúvida se sua origem é realmente natural.

O fato é que, ainda que se não possa estabelecer uma relação de causa e efeito, entre a alimentação humana e a pandemia, é inegável o impacto da segunda na primeira, sobretudo em países subdesenvolvidos, como o Brasil.

Embora as pessoas tenham passado a dispor de mais tempo para cozinhar e concentrar sua alimentação em legumes e verduras, o comércio eletrônico de snacks ${ }^{14}$ aumentou $722 \%$ durante a quarentena, de acordo com pesquisa realizada pela empresa de tecnologia Criteo, divulgada no portal da revista Exame, em 06 de maio de $2020^{15}$.

Esse cenário expõe idosos, crianças e adolescentes a uma intensificação de publicidade de alimentos substancialmente industrializados, em descompasso com a meta 2.1 do Objetivo de Desenvolvimento Sustentável 02, das Nações Unidas (2015):

Até 2030, acabar com a fome e garantir o acesso de todas as pessoas, em particular os pobres e pessoas em situações vulneráveis, incluindo crianças, a alimentos seguros, nutritivos e suficientes durante todo o ano. (sem negrito no original)

Esses alimentos recebem corantes, produtos químicos os mais diversos, entre sais e açucares, além de gordura saturada, a ponto de potencializar os riscos à saúde pública. Ou seja, enquanto as pessoas se limitavam para fugir dos riscos da COVID 19, terminaram por se expor a produtos nocivos à saúde individual.

\footnotetext{
${ }^{13}$ Reportagem da revista ISTO É - Novo coronavírus foi fabricado acidentalmente em laboratório chinês, diz descobridor do HIV -, publicada virtualmente em 17 abr. 2020, expõe que o cientista francês chega a essa conclusão, em razão do fato de a cidade de Wuan, na China, apresentar um laboratório especializado em Coronavirus, aliado à circunstância de que o gene do vírus apresenta sequências de outro vírus - o HIV - descoberto pelo próprio Montagnier, que exclui a possibilidade de mutação genética e aposta que algum incidente laboratorial como causa para o surgimento do vírus da pandemia de COVID 19.

${ }^{14} \mathrm{~A}$ palavra foi utilizada para compreender salgadinhos, chocolates, biscoitos, entre outros, de acordo com a reportagem que veicula a pesquisa.

15 Disponível em: https://exame.com/tecnologia/estudo-revela-os-produtos-mais-vendidos-do-e-commercedurante-a-quarentena/, acesso em 27 de set de 2020.
} 
O Governo poderia ter lançado mão do condicionante previsto no art. $37, \S 2^{\circ}$, do Código de Defesa do Consumidor, para limitar a publicidade desses alimentos durante a pandemia, ao argumento de que, neste período pandêmico, o consumo ampliado desses alimentos se revela um comportamento prejudicial à saúde do consumidor.

A procura por alimentos prontos, com baixo teor nutritivo e grande poder calórico, o refrigerante e água gaseificada em vez do suco natural, põe nossa sociedade em caminho inverso ao do Desenvolvimento Sustentável.

Aqui se vê que as oportunidades educacionais, com o impedimento de que a população esteja mais vulnerável à publicidade desse tipo de alimentação, não estão sendo garantidas. O Governo Federal não só não esclareceu mais intensamente a população dos riscos desses alimentos, como também não impediu que imagens lúdicas fossem reforçadas nesse momento.

Deixada à sorte, a sociedade brasileira ficou em casa, sujeita à imagem que a indústria alimentar oferece: alimentos saborosos, práticos, rápidos, prontos! Não foi dito a essa indústria que ela também precisa ser fraterna.

Nesse sentido, a lição de Luís Fernando Barzotto (2018, p. 85), para quem "a relação de Fraternidade é de responsabilidade recíproca: cada um é responsável pelo outro". Não se pode olvidar que por trás da abstração da indústria há pessoas, que precisam ser orientadas a assumir responsabilidades, o que envolve comportamentos positivos (adotar práticas que implementem alimentos saudáveis) e negativos (abster-se de imprimir imagens lúdicas de alimentos não saudáveis).

Aliás, é preciso pontuar: a Lei 14.016, de 23 de junho de 2020 veio para autorizar donos de restaurantes, fábricas, hotéis, hospitais e congêneres, que produzem alimentos em grande escala, a doar o excedente, desde que ainda estejam em condições de consumo humano.

O instrumento normativo não deixa de defender um discurso fraternal. No entanto, objetivou garantir segurança jurídica aos doadores, mais do que assegurar alimentação a quem dela necessitava.

Ao restringir a responsabilidade do doador aos casos em que agir com dolo, o legislador deixa inferir que a alimentação doada pode ser manejada com negligência, imperícia ou imprudência.

Por outro lado, a imediatividade do surgimento e propagação do vírus não pode ser 
justificativa para omissões do Governo e da Indústria. Embora a doença seja ainda desconhecida, já não são poucas as advertências quanto aos riscos. Na década de 1980, Ulrich Bech(1986, p. 10) já advertia quanto à socialização dos danos à natureza e quanto à intensa industrialização no mundo.

A Agenda 2030, da Organização das Nações Unidas, estabeleceu os Objetivos de Desenvolvimento Sustentável em 2015, os quais funcionam como um desdobramento ampliado dos Objetivos de Desenvolvimento do Milênio, estes fixados em setembro de 2000.

Há uma década, as Nações Unidas traçaram seus Objetivos para o Milênio, e um dos primeiros era exatamente a "redução, pela metade, do número de pessoas subnutridas", de maneira que houve tempo para que o Brasil implementasse ações que, mesmo diante de uma pandemia cuja certeza científica ainda é incipiente, permitissem à população condições de melhor escolher sua alimentação e preservar sua imunidade biológica.

O portal virtual ods.brasil.gov.br permite acompanhar o implemento de todos os Objetivos de Desenvolvimento Sustentável, e adota cinco critérios - 1. Não se aplica ao Brasil(cinza), 2. Sem metodologia global(vermelho), 3. Sem dados(azul), 4. Em análise/construção(amarelo) e 5.Produzido(verde).

Quanto à meta 2.1., observa-se que mesmo passados cinco anos da criação da Agenda 2030, poucas informações foram inseridas no Portal, que, no entanto, traz um dado preocupante: cerca de $25 \%$ de moradores de domicílios particulares apresentam insegurança alimentar. No âmbito rural, o número é ainda pior: $40 \%$ dos moradores de domicílio rural não têm segurança alimentar.

O ano de 2020 parece ser mais um ano de inércia governamental, e a pandemia não é a causa, pois se tem verificado que o Governo Federal tem tentado implementar uma agenda de normalidade em outras áreas, com a realização de obras de infraestrutura.

Até a década de 1980, o cigarro era símbolo de status social e de virilidade masculina. No entanto, em razão de uma contínua campanha de conscientização, e de restrições à publicidade e uma política tributária eficiente, hoje, o cigarro é elemento praticamente excluído da sociedade, sendo notórios seus efeitos na saúde humana e na tão desejada virilidade masculina.

O tratamento dado ao tabagismo demonstra que nosso país tem condições de enfrentar problemas sociais, conscientizando sua população e implementando comportamentos fraternais. 
É fato que o consumo de gordura em excesso, e de açúcares e corantes, não traz esse desequilíbrio social tão visível quanto no ato de fumar. Ninguém passa a ter diabetes em razão do consumo de refrigerante alheio. No entanto, o implemento de custos com saúde pública é uma consequência inevitável dessa má alimentação.

Por mais que se apontes ser esta apenas uma questão de utilitarismo ${ }^{16}$, na verdade traduz também uma típica questão de Desenvolvimento, pois não há como uma nação se desenvolver se seus cidadãos estiverem doentes.

No aspecto quântico, Danah Zohar, apud Carlos Ayres Britto(2016, p. 66), explica que o indivíduo é uma dualidade onda-partícula. Ou seja, movimento-estático, energiamatéria.

É por isso que o impacto da alimentação não está apenas no físico(partícula) do indivíduo. $\mathrm{O}$ aspecto psicológico(onda) também é influenciado. Nesse sentido, o Ministério da Saúde elege "uma dieta equilibrada" ${ }^{17}$ como primeira causa de prevenção à depressão - o mal do século, segundo a Organização Mundial da Saúde.

Uma sociedade deprimida não consegue empreender, e não conseguindo empreender, não tem como se desenvolver. Não quer isso dizer que o Desenvolvimento se limite à questão econômica, apenas que a renda, a saúde e educação, os três critérios de aferição do Índice de Desenvolvimento Humano(IDH), proposto por Mahbub Hu Haq e Amartya Sen ${ }^{18}$, estão diretamente ligados à alimentação.

Um povo que não se alimenta adequadamente demonstra falta de educação, passa a ter problemas generalizados de saúde e não consegue obter renda. Essa tríade nociva impede o Brasil de sair da $79^{a}$ posição no IDH.

Na edição da revista Época, edição de 29 de junho de 2020 (p. 26), o jornalista Guilherme Amado alerta acerca da fome que assola cerca de 8,5 milhões de pessoas em extrema pobreza e outras 23 milhões de pobres no Brasil, que necessitam de medidas eficientes e rápidas para minimizar os impactos da pandemia.

Certamente não são essas 31,5 de milhões de pessoas que estão incrementando as vendas de alimentos industrializados. Essas pessoas, que sequer contam com uma casa para

\footnotetext{
${ }^{16}$ Para melhor compreensão da teoria de Jeremy Bentham, remete-se à obra Justiça - o que é fazer a coisa certa - de Michael J. Sandel (2015, p 43-74), traz uma perspectiva prática do assunto.

${ }_{18}^{17}$ Conferir mais sobre a depressão em http://saude.gov.br/saude-de-a-z/depressao, acesso em 28 jun. 2020. Disponível em: https://www.ipea.gov.br/desafios/index.php?option=com_content\&view=article \&id=2294:catid=28\&Itemid=23 . Acesso em: 27 jun. 2020.
} 
"ficar em casa", não têm fonte de renda além do auxílio emergencial e não leem além das pichações urbanas, não estão entre as que bebem refrigerante várias vezes por semana.

O inusitado é que embora os consumidores de snacks sejam em geral pessoas com mais oportunidades econômicas, educacionais e sociais, elas terminaram cedendo ao apelo publicitário da indústria.

A preferência a alimentos industrializados embora gere renda, por outro lado, esfacela as oportunidades de uma outra camada de população: a que depende da agropecuária de subsistência.

É nesse sentido que o Estado precisa empreender esforços para concreção da Fraternidade jurídica, a fim de corrigir essa distorção: um prefere comprar morte, enquanto outro necessita vender vida.

\title{
5 DA AGROPECUÁRIA DANOSA AO MEIO AMBIENTE, UM OBSTÁCULO AO DESENVOLVIMENTO SUSTENTÁVEL
}

A certidão de nascimento ${ }^{19}$ do Brasil, escrita à pena de Pero Vaz de Caminha, registrava:

\begin{abstract}
Nela, até agora, não pudemos saber que haja ouro, nem prata, nem coisa alguma de metal ou ferro; nem lho vimos. Porém a terra em si é de muito bons ares, assim frios e temperados, como os de Entre Doiro e Minho, porque neste tempo de agora os achávamos como os de lá.

Águas são muitas; infindas. E em tal maneira é graciosa que, querendo-a aproveitar, dar-se-á nela tudo, por bem das águas que tem.(apud Marry del Priore, 2016).
\end{abstract}

A percepção do fidalgo português deu azo à máxima de que "em se plantando tudo dá”, expondo ao Antigo Mundo a fertilidade das terras tupiniquins. Se o Brasil dispunha terras férteis e "águas muitas", bastaria alimentar os rebanhos, e plantar e colher: a agricultura e a pecuária seriam então as atividades que garantiriam o desenvolvimento humano no Brasil.

No entanto, equilibrar a agropecuária e meio ambiente não é tão simples. Um relatório das Nações Unidas, publicado em novembro de 2006, aponta que o rebanho bovino mundial já produz mais gases nocivos à camada de ozônio do que todo o sistema de transporte terrestre do mundo.

\footnotetext{
${ }^{19}$ Marry del Priore (2016) afirma que A Carta, de 1500, é considerada o documento de fundação do Brasil.
} 
Por outro lado, o desmatamento é a segunda maior causa de mudanças climáticas. Nesse sentido, o Censo Agro 2017, do Instituto Brasileiro de Geografia e Estatística, mostra que $45 \%$ do território brasileiro já é destinado à pastagem, e outros $18 \%$ são destinados a lavouras. Ou seja, a criação de animais cativos (bovinos, caprinos, suínos e equinos) já utiliza três vezes mais espaço do que a plantação de legumes, verduras e frutas.

Considerando que que mais de $90 \%$ de todos os seres vivos do mundo hoje já são seres humanos e animais cativos (ANDERSEN e KUHN, 2014), observa-se que os riscos de zoonoses, como a COVID 19, são agravados na medida em que animais silvestres e selvagens passam a ter que dividir o habitat com animais diretamente ligados à alimentação humana.

Nesse sentido, o equilíbrio entre a produção agropecuária e a preservação do meio ambiente passa a ser o maior desafio para o desenvolvimento dessa nação que dispõe de solo fértil e água abundante, sob pena de passarmos sede no oásis. É exatamente por isso que o Constituinte reconheceu, no art. $225 / \mathrm{CF}^{20}$, que o meio ambiente ecologicamente equilibrado é direito de todos, e impôs à coletividade(fraterna) o dever de defendê-lo e preservá-lo para as presentes e futuras gerações.

Observa-se que a busca desse equilíbrio - o desenvolvimento humano pela agropecuária e a preservação do meio ambiente - é mais um determinante jurídico que condensa a Fraternidade, expressada no ponto como solidariedade intergeracional(art $225 / \mathrm{CF})$.

A meta 2.b. do ODS 02 consiste em "corrigir e prevenir as restrições ao comércio e distorções nos mercados agrícolas mundiais, incluindo a eliminação paralela de todas as formas de subsídios à exportação e todas as medidas de exportação com efeito equivalente, de acordo com o mandato da Rodada de Desenvolvimento de Doha”.

A intenção é evitar que países já desenvolvidos continuem subsidiando sua agropecuária, ocasionando o chamado dumpping, ou seja, a venda de produtos por preço abaixo do valor de mercado, no plano internacional.

No entanto, é preciso considerar os dados da Secretaria Especial da Articulação Social e do Instituto Brasileiro de Geografia e Estatísticas, divulgados no portal virtual www.odsbrasil.gov.br (ver referências), de que 35\% dos domicílios rurais brasileiros ainda apresentam insegurança alimentar. Diante desse cenário, é preciso pontuar que a agricultura

\footnotetext{
${ }^{20}$ Art. 225 da Constituição Federal: "Todos têm direito ao meio ambiente ecologicamente equilibrado, bem de uso comum do povo e essencial à sadia qualidade de vida, impondo-se ao Poder Público e à coletividade o dever de defendê-lo e preservá-lo para as presentes e futuras gerações."
} 
familiar seria impulsionada se houvesse a concessão de financiamentos subsidiados, ainda que por um período de tempo inferior ao estabelecido para atingimento dos Objetivos, que é 2030.

O impedimento de subsídios se mostra eficiente a longo prazo, porque neutraliza a concorrência desleal por parte de países desenvolvidos, porém, não garante a curto prazo que países como o Brasil deem incentivos ao pequeno e médio agricultor e pecuarista.

Nesse sentido, cabe ao Estado fomentar agricultores que produzam alimentos livres de agrotóxicos, criando alternativas de inserção no mercado, como a abertura de linhas de crédito não subsidiadas, o incentivo ao estudo e manejo racional da terra, e o fortalecimento de um sistema hídrico eficiente, que amenize a aridez da Região Nordeste, de forma a diminuir as desigualdades regionais, como objetiva nosso constituinte.

Sanções premiais para produtores rurais que não utilizem inseticidas e para pecuaristas que minimizem o sofrimento animal, bem como diminuam o uso de hormônios, apresentam-se como possíveis modeladores de uma nova ordem fraternal, que privilegia o bem de todos, não descurando do sofrimento de poucos.

A política tributária também deve privilegiar essas atividades, não se podendo aceitar que os pequenos produtores rurais percebam uma incidência de tributos nos mesmos patamares das grandes fazendas e indústrias do setor.

\section{CONCLUSÃO}

A pandemia trouxe um cenário de incertezas e potencializou vulnerabilidades. Exatamente por isso, pôs em maior evidência a necessidade de que o ser humano precisa levar em conta a presença constante de riscos, em razão da sustentabilidade do nosso desenvolvimento tecnológico e científico estar ligada à preservação do meio ambiente.

Nesse contexto, discursos políticos tentaram antagonizar economia e saúde pública. No entanto, os discursos em favor da economia entoaram apenas as falas dos mais poderosos, que se autodenominaram vulneráveis em razão das limitações impostas pelo isolamento social, permanecendo inaudíveis os gritos daqueles que realmente sempre estiveram vulnerabilizados, porque sequer casa tinham para ficar.

No campo específico da alimentação humana, o Brasil seguiu desconsiderando os riscos, e continuou praticamente inerte na implementação do Objetivo de Desenvolvimento Sustentável 02, das Nações Unidas. Com ações desarticuladas, omissões perigosas, o país 
seguiu negligenciando o trato da alimentação saudável e não privilegiou uma agricultura sustentável. Também se manteve leniente na busca de equalizar a proteção ao meio ambiente e a produção rural.

A Fraternidade, por conseguir dividir responsabilidades entre todos, mostra-se como eficiente vetor para ações de enfrentamento da pandemia, mas não só. Propicia também a construção de uma sociedade desenvolvida.

Esperar que as pessoas individualmente desenvolvam sentimentos altruístas é uma utopia, porém, fomentar paradigmas jurídicos que solidifiquem uma sociedade fraterna é um objetivo a ser perseguido com a mesma tenacidade com que os riscos devem ser enfrentados.

Conclui-se, portanto, que a alimentação saudável e a agropecuária sustentável, em equilíbrio com a preservação do meio ambiente, são propulsoras do desenvolvimento humano, razão por que o Brasil deve engendrar políticas públicas fraternais urgentes para implementar o ODS 02, fomentando o comportamento de todos a bem de todos.

\section{REFERÊNCIAS}

ABDALA, Vítor. Trabalhadores autônomos somam 24 milhões, diz IBGE. Agência Brasil, Economia, Notícia. 28 jun. 2019. Disponível em: https://agenciabrasil.ebc.com.br/economia/noticia/2019-06/trabalhadores-autonomos-somam24-milhoes-no-pais-diz-ibge. Acesso em: 21 de jun. 2020.

AMADO, Guilherme. A covid e a pressa de 31 milhões de brasileiros. Época. São Paulo: Globo, p. 26-27. 29 jun. 2020.

ANJOS FILHO, Robério Nunes dos. Direito ao Desenvolvimento. São Paulo: Saraiva, 2013.

AQUINI, Marco. Fraternidade e direitos humanos. In: BAGGIO, Antonio Maria(Org.). $O$ Princípio Esquecido/1. São Paulo: Cidade Nova, 2008.

ARISTÓTELES. Ética a Nicômaco. São Paulo: Martin Claret, 2003.

BAGGIO, Antonio Maria(org.). O Princípio Esquecido/1. São Paulo: Cidade Nova, 2008.

BRASIL. Constituição da República Federativa do Brasil, de 05 de outubro de 1988. Disponível em: http://www.planalto.gov.br/ccivil_03/constituicao/constituicao.htm. Acesso em: 26 jun. 2020.

Instituto Brasileiro de Geografia e Estatística. Censo Agro 2017, resultados definitivos. 2017. Disponível em:

https://censos.ibge.gov.br/agro/2017/templates/censo_agro/resultadosagro/estabelecimentos.ht ml. Acesso em: 08 ago. 2020. 
. Instituto Brasileiro de Geografia e Estatística e Secretaria Especial de Articulação Social. Indicador 2.1.2 - Prevalência de insegurança alimentar moderada ou grave, baseado na Escala de Experiência de Insegurança Alimentar (FIES). Disponível em: https://odsbrasil.gov.br/objetivo2/indicador212. 2020. Acesso em: 08 ago. 2020.

Instituto de Pesquisa Econômica Aplicada. Desafios em desenvolvimento.

Questões de desenvolvimento: medindo o bem-estar das populações. 2009 . Ano 7. Ed 55, 17/11/2009. Acesso em 27 set. 2020.

Lei 8.078, de 11 de setembro de 1990. Disponível em:

http://www.planalto.gov.br/ccivil_03/LEIS/L8078.htm. Acesso em: 27 jun. 2020.

Ministério da Saúde. Brasil confirma primeiro caso da doença. Disponível em: https://www.saude.gov.br/noticias/agencia-saude/46435-brasil-confirma-primeiro-casode-novo-coronavirus. Acesso em: 21 de jun. 2020.

Ministério da Saúde. Depressão: causas, sintomas, tratamentos, diagnóstico e prevenção. Disponível em: http://saude.gov.br/saude-de-a-z/depressao. Acesso em: 21 jun. 2020.

BRITTO, Carlos Ayres. O humanismo como categoria constitucional. Belo Horizonte: Fórum, 2016.

BARZOTTO, Luís Fernando. Fraternidade: uma aproximação conceitual. In:

MACHADO, Carlos Augusto Alcântara; BARZOTTO, Luciane Cardoso; MACHADO, Clara Cardoso. DIREITO E FRATERNIDADE: em busca da concretização. Aracaju: EDUNIT, 2018.

BECK, Ulrick. Sociedade de risco: rumo a uma outra modernidade. Tradução de Sebastião Nascimento. 2 ed. São Paulo: Editora 34, 2011.

CARBINATTO, Bruno. Resumindo: qual a diferença entre lockdown e quarentena? Superinteressante. São Paulo, maio 2020. Seção Saúde. Disponível em:

https://super.abril.com.br/saude/resumindo-qual-a-diferenca-entre-lockdown-e-quarentena/. Acesso em: 05 ago. 2020.

COWSPIRACY: o segredo da sustentabilidade. Produção de Kip Andersen e Keegan Kuhn. Roteiro: Kip Andersen e Keegan Kuhn, 2014. 1 vídeo (90 min). Netflix. Disponível em: https://www.netflix.com/search?q=cospiracy\&jbv=80033772\&jbp=0\&jbr=0. Acesso em: 4 jul. 2020.

GOMES, Laurentino, ESCRAVIDÃO - VOLUME I. Do primeiro leilão de cativos em Portugal até a morte de Zumbi de Palmares. Rio de Janeiro: Globo Livros, 2019. 
HOBBES, Thomas. Leviatã. Matéria, forma e poder de um Estado eclesiástico e civil. (Tradução de João Paulo Monteiro e Maria Beatriz Nizza da Silva). 3. ed. São Paulo: AbrilCultural, 1983. Col. Os Pensadores.

ISTO É. Novo coronavírus foi fabricado acidentalmente em laboratório chinês, diz descobridor do HIV. Da Redação, 17 abr. 2020. Disponível em: https://istoe.com.br/Novo-coronavIrus-foifabricado-em-laboratorio-chines-diz-descobridor-do-HIV. Acesso em: 6 ago. 2020.

\section{JABORANDY, Clara Cardoso Machado. A Fraternidade no Direito Constitucional} Brasileiro: Um Instrumento para Proteção de Direitos Fundamentais Transindividuais. Tese(Doutorado em Direito Público) - Faculdade de Direito, Universidade Federal da Bahia. Disponível em:

https://repositorio.ufba.br/ri/bitstream/ri/20048/1/CLARA\%20CARDOSO\%20MACHADO\% 20JABORANDY.pdf. Acesso em: 1 ago. 2020.

LOUREIRO, Rodrigo. Estudo revela os produtos mais vendidos do e-commerce durante a quarentena. Revista Exame, Tecnologia, 6 de maio de 2020. Disponível em:

https://exame.com/tecnologia/estudo-revela-os-produtos-mais-vendidos-do-e-commercedurante-a-quarentena/. Acesso em: 27 jun. 2020.

MACHADO, Carlos Augusto Alcântara. A Fraternidade como categoria jurídica: fundamentos e alcance(expressão do constitucionalismo fraternal). Curitiba: Appris, 2017.

MACHADO, Carlos Augusto Alcântara; BARZOTTO, Luciane Cardoso; MACHADO, Clara Cardoso. DIREITO E FRATERNIDADE: em busca da concretização. Aracaju: EDUNIT, 2018.

NAÇÕES UNIDAS. Declaração Universal dos Direitos Humanos. 2020. Disponível em: https://nacoesunidas.org/wp-content/uploads/2018/10/DUDH.pdf. Acesso em: 9 ago. 2020.

Entrega de alimentos a estudantes tem continuidade no Brasil durante pandemia. 2020. Disponível em: https://nacoesunidas.org/entrega-de-alimentos-a-estudantestem-continuidade-no-brasil-durante-a-pandemia/. Acesso em: 26 jun. 2020.

. Objetivos de Desenvolvimento do Milênio. 2020. Disponível em:

https://nacoesunidas.org/tema/odm/. Acesso em: 27 jun. 2020.

Objetivos de Desenvolvimento Sustentável: Objetivo 2. Acabar com a fome, alcançar a segurança alimentar e melhoria da nutrição e promover a agricultura sustentável. 2020. Disponível em: https://nacoesunidas.org/pos2015/ods2/. Acesso em: 27 de jun. 2020.

Objetivos de Desenvolvimento Sustentável: Objetivo 2. Acabar com a fome, alcançar a segurança alimentar e melhoria da nutrição e promover a agricultura sustentável. 2020. Disponível em https://nacoesunidas.org/pos2015/ods2/. Acesso em: 27 de jun. 2020. 
Rearing cattle produces more greenhouse gases than driving cars, UN report warns. 2006. Disponível em: https://news.un.org/en/story/2006/11/201222-rearing-cattleproduces-more-greenhouse-gases-driving-cars-un-report-warns . Acesso em: 30 jun. 2020.

Programa Bolsa Família é exemplo de erradicação de pobreza, afirma relatório da ONU. 2011. Disponível: em https://nacoesunidas.org/programa-bolsa-familia-eexemplo-de-erradicacao-de-pobreza-afirma-relatorio-da-onu/. Acesso em: 26 jun. 2020.

PRIORE, Marry del. Em se plantando tudo dá. Histórias da Gente Brasileira. 20 abr. 2016. Disponível em: http://historiasdagentebrasileira.com.br/site/em-se-plantando-tudo-da/. Acesso em: 28 jun. 2020.

SANDEL, Michel J. Justiça - o que é fazer a coisa certa. - 17. ed. - Rio de Janeiro: Civilização Brasileira, 2015.

SEN, Amartya. Desenvolvimento como Liberdade, tradução de Laura Teixeira Motta e revisão técnica de Ricardo Doninelli Mendes. São Paulo: Companhia de Bolso, 2010.

SUPIOT, Alain. Homo juridicus: ensaio sobre a função antropológica do direito. Tradução Maria Emantina de Almeida Prado Galvão. São Paulo: WMF Martins Fontes, 2007. 